Jurnal Matematika UNAND

Vol. VIII No. 2 Hal. 149 - 156

Edisi Agustus 2019

ISSN : 2303-291X

(C)Jurusan Matematika FMIPA UNAND

\title{
ANALISIS MODEL PEGAS-MAGNET
}

\author{
WARDATUL JANNAH, MAHDHIVAN SYAFWAN, RIRI LESTARI \\ Program Studi S1 Matematika, \\ Fakultas Matematika dan Ilmu Pengetahuan Alam, Universitas Andalas, \\ Kampus UNAND Limau Manis Padang, Indonesia. \\ email : wejejannah@gmail.com
}

Diterima 22 Juni 2019 Direvisi 6 Juli 2019 Dipublikasikan 4 Agustus 2019

\begin{abstract}
Abstrak. Dalam makalah ini dibahas model pegas-magnet dengan kondisi beban yang digantungkan pada pegas merupakan sebuah magnet. Tepat di bawah magnet yang digantung terdapat magnet lain yang identik dan dipasang permanen di lantai dengan posisi kutub yang berlawanan dengan magnet pada beban, sehingga menghasilkan gaya luar berupa gaya tarik magnetik. Titik kesetimbangan sistem yang diperoleh dipengaruhi oleh konstanta pegas $k$. Hasil analisis terhadap titik kesetimbangan menunjukkan bahwa konstanta pegas $k$ berada dalam selang $\left[\frac{5^{5}}{4^{4} L^{5}}, \infty\right)$, dimana $L$ menyatakan jarak antara posisi setimbang dengan magnet yang berada di lantai. Dari analisis kestabilan diperoleh bahwa titik kesetimbangan yang nilainya kurang atau sama dengan $\frac{L}{5}$ merupakan titik kesetimbangan yang stabil. Selanjutnya dilakukan simulasi numerik untuk mengkonfirmasi hasil-hasil analisis kestabilan yang diperoleh.
\end{abstract}

Kata Kunci: Sistem Pegas-Magnet, Titik Kesetimbangan, Konstanta Pegas, Analisis Kestabilan

\section{Pendahuluan}

Permasalahan dalam kehidupan sehari-hari dapat disajikan dalam bentuk bahasa matematika melalui suatu proses yang biasa dikenal dengan pemodelan matematika. Salah satu topik pemodelan matematika yang sering dibahas adalah gerak osilasi yang dihasilkan oleh beban yang memiliki massa dan digantung pada pegas. Permasalahan ini dikenal sebagai sistem pegas-massa [5].

Gerak osilasi yang dihasilkan oleh sistem pegas-massa dimodelkan secara sederhana dalam bentuk persamaan diferensial biasa orde dua. Pengkonstruksian model sistem pegas-massa dilakukan dengan menerapkan Hukum II Newton. Gaya-gaya yang bekerja pada sistem pegas-massa adalah gaya berat beban, gaya pulih pegas yang mengikuti Hukum Hooke, gaya redaman, dan gaya luar [3].

Beberapa penelitian telah membahas pengembangan terhadap sistem pegasmassa ini. Sebagai contoh, penelitian yang melakukan perbaikan pada model untuk mengetahui pengaruh massa pegas terhadap osilasi dari sistem pegas-massa $[2,7]$. Demikian juga penelitian tentang perilaku osilasi sistem yang dihasilkan oleh pegas plastik dan nonheliks juga telah dilakukan [6]. Pada penelitian lain juga telah dibahas pengaruh dari perubahan panjang alami pegas (untuk diameter tetap) terhadap 
perilaku konstanta pegas, frekuensi sudut, dan faktor redaman pada osilasi sistem [8].

Dalam makalah ini akan ditinjau kasus pegas yang digantung di langit-langit dan diberi beban berupa magnet yang dikaitkan di bagian bawah. Kemudian tepat di bawah beban terdapat magnet lain yang identik dan dipasang permanen di lantai. Diasumsikan gaya tarik dan gaya tolak pada kedua magnet menjadi satu-satunya sumber gaya luar yang bekerja pada sistem. Sistem ini dikenal sebagai sistem pegasmagnet dan dimodelkan secara sederhana dalam referensi [4].

\section{Beberapa Definisi}

\subsection{Konstruksi Model Pegas-Magnet}

Sistem pegas magnet dikonstruksi dengan mengabaikan gaya redaman pegas dan beban yang digantung pada pegas merupakan sebuah magnet. Kemudian tepat di bawah beban tersebut terdapat magnet lain yang identik dan dipasang permanen di lantai (perhatikan Gambar 1). Model pergerakan beban tersebut dapat ditulis sebagai berikut [4].

$$
m \ddot{x}+k x=F(t),
$$

dimana $x(t)$ menyatakan perpindahan beban magnet dari posisi setimbang dan $F(t)$ adalah gaya luar yang dikenakan pada beban. Diasumsikan bahwa gaya luar yang bekerja pada sistem pegas ini hanya bersumber dari interaksi magnetik antara dua magnet yang saling identik.

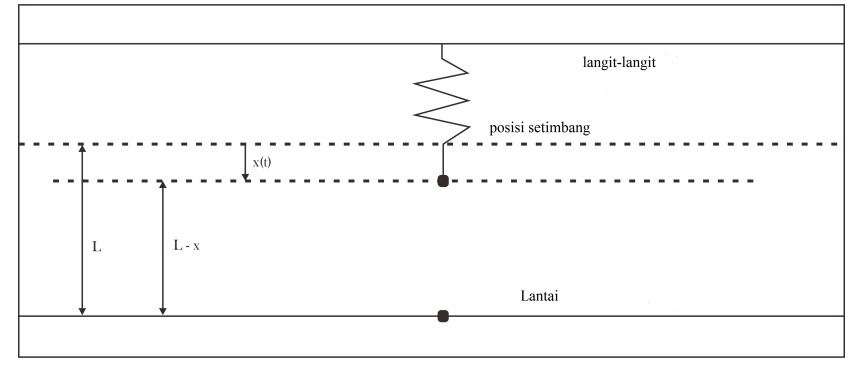

Gambar 1. Sistem pegas-magnet.

Diketahui bahwa gaya magnetik antara dua magnet proporsional terhadap $\pm \frac{1}{z^{4}}$, dimana $z$ adalah jarak antara dua magnet [9]. Pada Gambar 1, jarak antara dua magnet adalah $L-x$. Dengan demikian gaya luar $F(t)$ proporsional dengan

$$
\pm \frac{1}{(L-x)^{4}} \text {. }
$$

Dengan mengasumsikan massa beban sebesar satu satuan massa dan konstanta proporsional gaya magnetik adalah satu, maka dari persamaan (2.1) dan gaya luar (2.2) sistem pegas-magnet dapat dimodelkan oleh

$$
\ddot{x}+k x= \pm \frac{1}{(L-x)^{4}} .
$$


Misalkan magnet yang digantung pada pegas memiliki kutub utara di bagian atas dan kutub selatan di bagian bawah. Begitupun untuk magnet yang berada di lantai. Kutub selatan magnet yang digantung pada pegas akan menarik kutub utara magnet yang berada di lantai. Dengan mengambil tanda positif (kasus gaya tarik magnet) pada persamaan (2.3), maka model sistem pegas-magnet pada kasus ini dapat dinyatakan dalam bentuk

$$
\ddot{x}+k x=\frac{1}{(L-x)^{4}} .
$$

Persamaan (2.4) dapat disederhanakan menjadi suatu sistem persamaan diferensial orde satu dengan memisalkan

$$
\dot{x}=y,
$$

sehingga $\dot{y}=\ddot{x}$. Dengan pemisalan ini, persamaan (2.4) dapat ditulis menjadi

$$
\dot{y}=-k x+\frac{1}{(L-x)^{4}} .
$$

Persamaan (2.5) dan (2.6) membentuk sistem persamaan diferensial orde satu nonlinier homogen.

\subsection{Titik Kesetimbangan}

Titik kesetimbangan dari sistem (2.5) dan (2.6) dapat ditentukan dengan menetapkan $x$ dan $y$ sebagai fungsi konstan (tidak bergantung terhadap waktu $t$ ), sehingga $\dot{x}=0$ dan $\dot{y}=0$. Titik kesetimbangan dari sistem (2.5) dan (2.6) diberikan oleh $\left(x^{*}, y^{*}\right)$, dimana

$$
y^{*}=0,
$$

dan $x^{*}$ memenuhi

$$
-k x^{*}+\frac{1}{\left(L-x^{*}\right)^{4}}=0 .
$$

Dari persamaan (2.8) diperoleh

$$
k=\frac{1}{x^{*}\left(L-x^{*}\right)^{4}} \text { dengan } 0<x^{*}<L .
$$

Karena $y^{*}$ selalu nol, maka untuk selanjutnya titik kesetimbangan sistem (2.5)-(2.6) diberikan oleh $x^{*}$.

Untuk melihat bagaimana pengaruh konstanta pegas $k$ terhadap titik kesetimbangan sistem, maka perlu diselidiki terlebih dahulu interval nilai $k$ agar titik kesetimbangan $x^{*}$ berada dalam interval buka $(0, L)$. Dengan demikian, $k$ pada persamaan (2.9) sekarang dapat dipandang sebagai fungsi yang dipengaruhi oleh $x^{*}$, yaitu

$$
k\left(x^{*}\right)=\frac{1}{x^{*}\left(L-x^{*}\right)^{4}} .
$$

Perhatikan bahwa $\lim _{x^{*} \rightarrow L} k\left(x^{*}\right)=\infty$ dan $\lim _{x^{*} \rightarrow 0} k\left(x^{*}\right)=\infty$. Kedua hasil limit di atas menunjukkan bahwa nilai konstanta pegas $k$ tidak memiliki batas atas. Batas bawah 
dari konstanta pegas $k$ dapat ditentukan dengan mengetahui berapa titik minimum dari fungsi $k\left(x^{*}\right)$. Karena $k\left(x^{*}\right)$ tidak memiliki titik ujung dan titik singular, maka $k\left(x^{*}\right)$ mencapai titik kritis saat turunannya sama dengan nol, yaitu

$$
\frac{d}{d x^{*}}\left(\frac{1}{x^{*}\left(L-x^{*}\right)^{4}}\right)=0
$$

Persamaan (2.11) dapat diselesaikan dengan menggunakan aturan turunan sehingga diperoleh $x^{*}=\frac{L}{5}$. Akibatnya diperoleh $k\left(\frac{L}{5}\right)=\frac{5^{5}}{4^{4} L^{5}}$. Oleh karena itu, nilai kons tanta pegas $k$ haruslah berada pada selang $\left[\frac{5^{5}}{4^{4} L^{5}}, \infty\right)$.

Sebagai contoh, untuk $L=5$, titik kesetimbangan $x^{*}$ dapat diperoleh jika nilai konstanta pegas $k$ berada dalam selang $[0.00390625, \infty)$. Dengan bantuan Maple didapatkan hasil sebagai berikut :

(a) Untuk konstanta pegas $k=0.4$, diperoleh dua titik kesetimbangan, yaitu $x^{*}=0.004012866981$ dan $x^{*}=4.117259737$.

(b) Untuk konstanta pegas $k=0.04$, diperoleh dua titik kesetimbangan, yaitu $x^{*}=0.04135105135$ dan $x^{*}=3.346790595$.

(c) Untuk konstanta pegas $k=0.00390625$, diperoleh dua titik kesetimbangan, yaitu $x^{*}=1$ dan $x^{*}=1$.

\section{Analisis Kestabilan}

Matriks Jacobian dari sistem (2.5) dan (2.6) adalah

$$
J(x, y)=\left(\begin{array}{cr}
0 & 1 \\
-k+\frac{4}{\left(L-x^{*}\right)^{5}} & 0
\end{array}\right) .
$$

Nilai eigen dari matriks Jacobian (3.1) adalah

$$
\begin{gathered}
\lambda_{1}=\sqrt{-k+\frac{4}{\left(L-x^{*}\right)^{5}}}, \\
\lambda_{2}=-\sqrt{-k+\frac{4}{\left(L-x^{*}\right)^{5}}} .
\end{gathered}
$$

Selanjutnya kriteria kestabilan dari titik kesetimbangan $x^{*}$ diberikan dalam teorema berikut.

Teorema 3.1. Misalkan $L>0$ dan $k \geq \frac{5^{5}}{4^{4} L^{5}}$, maka titik kesetimbangan $x^{*} \leq \frac{L}{5}$ merupakan titik kesetimbangan yang stabil.

Bukti. Karena $L>0$ dan $k \geq \frac{5^{5}}{4^{4} L^{5}}$, maka $-k \leq-\frac{5^{5}}{4^{4} L^{5}}$. Dengan demikian diperoleh $-k+\frac{4}{\left(L-x^{*}\right)^{5}} \leq 0$. Hal ini mengakibatkan nilai eigen $\lambda_{1}$ dan $\lambda_{2}$ bernilai nol atau imajiner murni (yaitu $\operatorname{Re}\left(\lambda_{1}\right)$ dan $\operatorname{Re}\left(\lambda_{2}\right)$ bernilai 0$)$. Oleh karena itu, berdasarkan matriks Jacobian pada persamaan (3.1), diperoleh nilai eigen yang bernilai non positif, sehingga dapat disimpulkan bahwa titik kesetimbangan $x^{*} \leq \frac{L}{5}$ merupakan titik kesetimbangan yang stabil. 


\subsection{Simulasi Numerik}

Pada bagian ini dibahas hasil penyelesaian numerik dari sistem pegas-magnet (2.5)(2.6) untuk $L=5$ serta beberapa nilai $k$ dan syarat awal yang berbeda. Dalam hal ini digunakan metode Runge-Kutta orde 4 dengan ukuran langkah $h=0.1$. Hasil numerik ini juga untuk mengkonfirmasi hasil analisis kestabilan yang telah dibahas sebelumnya.

(1) Nilai awal $x(0)=0$ dan $\dot{x}(0)=0$ dengan konstanta pegas $k=0.4$.

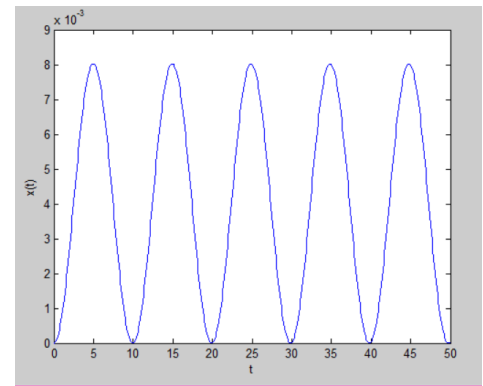

Gambar 2. Solusi sistem pegas-magnet dengan $L=5, k=0.4$, dan syarat awal $x(0)=0$ dan $\dot{x}(0)=0$.

Pada Gambar 2 dapat dilihat bahwa di saat-saat awal, simpangan $x(t)$ bernilai positif. Hal ini menunjukkan bahwa beban pada awalnya tertarik ke bawah oleh magnet di lantai. Selanjutnya, beban tertarik ke atas karena gaya pulih pegas, kemudian kembali bergerak ke bawah karena gaya tarik magnet, dan begitu seterusnya. Hal ini menghasilkan gerakan osilasi seperti yang ditunjukkan pada Gambar 2. Perhatikan pula bahwa beban berosilasi di sekitar titik kesetimbangan $x^{*}=0.004012866981$, yang mengkonfirmasi bahwa titik kesetimbangan stabil.

(2) Nilai awal $x(0)=0$ dan $\dot{x}(0)=0$ dengan konstanta pegas $k=0.04$.

Pada Gambar 3 diberikan visualisasi solusi numerik dari sistem pegasmagnet dengan $L=5$ dan syarat awal yang sama dengan Gambar 2, namun dengan konstanta pegas $k=0.004$. Dari Gambar 3 dapat dilihat bahwa sistem pegas-magnet mengalami osilasi yang sama seperti Gambar 2, namun dengan amplitudo (simpangan maksimum) yang berbeda, sebagai akibat dari pengaruh konstanta pegas.

Dari kedua gambar dapat disimpulkan bahwa semakin besar konstanta pegas maka amplitudo osilasi menjadi semakin besar. Hal ini sesuai dengan Hukum Hooke yang menyatakan bahwa semakin kecil konstanta pegas maka semakin kecil pula gaya pulih pegas yang dihasilkan. Akibatnya, untuk konstanta pegas yang lebih kecil, beban tertarik lebih kuat oleh magnet di lantai, sehingga menghasilkan simpangan yang lebih besar. Perhatikan pula pada Gambar 3 bahwa beban berosilasi di sekitar titik kesetimbangan $x^{*}=$ 0.04135105135, yang mengkonfirmasi bahwa titik kesetimbangan stabil. 


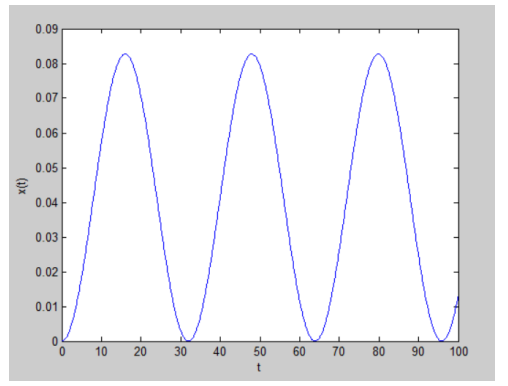

Gambar 3. Solusi sistem pegas-magnet dengan $L=5, k=0.04$, dan syarat awal $x(0)=0$ dan $\dot{x}(0)=0$.

(3) Nilai awal $x(0)=0$ dan $\dot{x}(0)=0.1$ dengan konstanta pegas $k=0.4$.

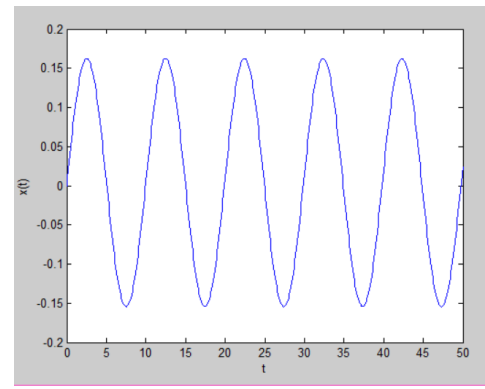

Gambar 4. Solusi sistem pegas-magnet dengan $L=5, k=0.4$, dan syarat awal $x(0)=0$ dan $\dot{x}(0)=0.1$.

Pada Gambar 4 dapat dilihat bahwa di saat-saat awal simpangan $x(t)$ bernilai positif, yang menunjukkan bahwa beban pada awalnya tertarik ke bawah oleh magnet di lantai. Selanjutnya beban tertarik ke atas karena gaya pulih pegas, kemudian kembali bergerak ke bawah karena gaya tarik magnet, dan begitu seterusnya. Hal ini menghasilkan gerakan osilasi seperti yang ditunjukkan pada Gambar 4. Karena beban diberi kecepatan awal sebesar 0.1, maka simpangan beban menjadi lebih besar. Perhatikan pula bahwa beban berosilasi di sekitar titik kesetimbangan $x^{*}=0.004012866981$, yang mengkonfirmasi bahwa titik kesetimbangan tersebut stabil.

(4) Nilai awal $x(0)=0$ dan $\dot{x}(0)=-0.1$ dengan konstanta pegas $k=0.4$.

Pada Gambar 5 dapat dilihat bahwa di saat-saat awal simpangan $x(t)$ bernilai negatif, yang menunjukkan bahwa beban pada awalnya tertarik ke atas karena diberi kecepatan awal negatif. Pada Gambar 5 juga dapat dilihat bahwa beban berosilasi di sekitar titik kesetimbangan $x^{*}=$ 0.004012866981, yang kembali mengkonfirmasi bahwa titik kesetimbangan tersebut stabil. Dari Gambar 4 dan 5 dapat dilihat pengaruh kecepatan awal terhadap arah simpangan beban pada saat awal berosilasi. Namun 


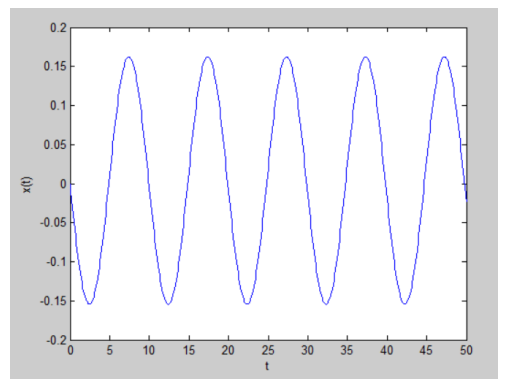

Gambar 5. Solusi sistem pegas-magnet dengan $L=5, k=0.4$, dan syarat awal $x(0)=0$ dan $\dot{x}(0)=-0.1$.

besaran kecepatan awal yang sama tidak mempengaruhi besar simpangan yang dihasilkan.

(5) Nilai awal $x(0)=1$ dan $\dot{x}(0)=0$ dengan konstanta pegas $k=\frac{5^{5}}{4^{4} 5^{5}}$.

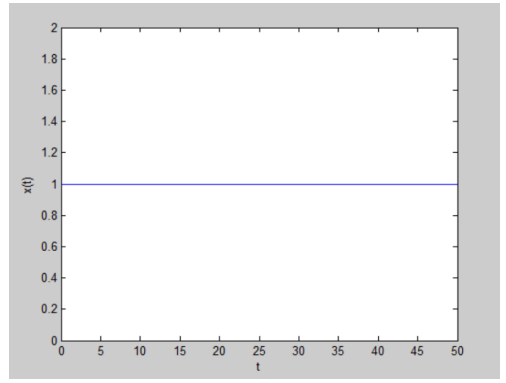

Gambar 6. Solusi sistem pegas-magnet dengan $L=5, k=\frac{5^{5}}{4^{4} 5^{5}}$, dan syarat awal $x(0)=1$ dan $\dot{x}(0)=0$.

Pada Gambar 6 diberikan visualisasi solusi numerik dari sistem pegasmagnet dengan $L=5, k=\frac{5^{5}}{4^{4} 5^{5}}$, dan syarat awal $x(0)=1$ dan $\dot{x}(0)=0$, artinya sistem memiliki simpangan awal sebesar 1 tetapi tidak memiliki kecepatan awal. Berbeda dengan gambar-gambar sebelumnya, karena konstanta pegas yang digunakan adalah nilai minimum, maka hal ini mengakibatkan nilai eigen bernilai 0. Dengan demikian, solusi yang dihasilkan bernilai konstan. Hal ini mengkonfirmasi bahwa kestabilan titik kesetimbangan $x^{*}=1$.

\section{Kesimpulan}

Dari uraian pada pembahasan dapat dilihat bahwa model pergerakan beban pada sistem pegas-magnet diberikan oleh persamaan berikut:

$$
\ddot{x}+k x=\frac{1}{(L-x)^{4}} .
$$


Hasil analisis terhadap titik kesetimbangan menyimpulkan bahwa konstanta pegas $k$ berada dalam selang $\left[\frac{5^{5}}{4^{4} L^{5}}, \infty\right)$, dimana $L$ menyatakan jarak antara posisi setimbang dengan posisi magnet yang berada di lantai. Dari hasil analisis kestabilan diperoleh bahwa titik kesetimbangan yang kurang atau sama dari $\frac{L}{5}$ merupakan titik kesetimbangan yang stabil.

Dari simulasi numerik diperoleh hasil-hasil berikut:

(1) Meskipun tidak memiliki simpangan awal dan kecepatan awal, beban pada pegas tetap mengalami osilasi, kecuali ketika $k=\frac{5^{5}}{4^{4} L^{5}}$ yang menghasilkan solusi konstan.

(2) Konstanta pegas yang lebih kecil mengakibatkan beban tertarik lebih kuat oleh magnet di lantai, sehingga akan menghasilkan simpangan yang lebih besar.

(3) Kecepatan awal pada beban akan mempengaruhi arah pergerakan beban, namun besaran kecepatan awal yang sama tidak mempengaruhi besar simpangan yang dihasilkan.

(4) Hasil-hasil numerik mengkonfirmasi kestabilan titik kesetimbangan.

\section{Ucapan Terima kasih}

Penulis mengucapkan terima kasih kepada ibu Dr. Haripamyu, bapak Prof. Dr. Muhafzan dan ibu Monika Rianti Helmi, M.Si yang telah memberikan masukan dan saran sehingga makalah ini dapat diselesaikan dengan baik.

\section{Daftar Pustaka}

[1] Anton, H. 2005. Elementary Linear Algebra. Ninth Edition. Wiley.

[2] Bowen, J. M. 1982. Slinky Oscillation and The Notion of Effective Mass. American Journal of Physics, 50, 1145

[3] Boyce, W. E dan Prime. 2001 Elementary Differential Equations and Boundary Value Problems. John Wiley Sons, New York

[4] Fay, T. H dan L. Mead. 2005. A Magnet Spring Model. International journal of Mathematical Education in Science and Technology 37(3): 321 - 329

[5] Halliday, David, Robert Resnick dan Jearl Walker. 2005. Fisika Dasar Edisi 7 Jilid 1. Erlangga, Jakarta

[6] McDonald, F. A. 1980. Deceptively Simple Harmonic Motion : A Mass on A Spiral Spring. American Journal of Physics 48: 189

[7] Sears, F. A. 1969. A Demonstration of the Spring-Mass Correction. American Journal of Physics 37: 645

[8] Triana, C. A dan F Fajardo. 2012. The Influence of Spring Lenght on the hysical arameters of Simple Harmonic Motion. European Journal of Physics 33: 219

[9] Yung, Kar W , Peter B. Landecker dan Daniel D. Villani. 1998. An Analytic Solution for the Force Between Two Magnetic Dipoles. American Journal of Physics 9: 39 - 52 